\title{
Marixanthomonas ophiurae gen. nov., sp. nov., a marine bacterium of the family Flavobacteriaceae isolated from a deep-sea brittle star
}

Correspondence Lyudmila A. Romanenko Iro@piboc.dvo.ru

\author{
Lyudmila A. Romanenko, ${ }^{1}$ Masataka Uchino, ${ }^{2}$ Galina M. Frolova ${ }^{1}$ \\ and Valery V. Mikhailov ${ }^{1}$
}

\begin{abstract}
'Pacific Institute of Bioorganic Chemistry, Far-Eastern Branch, Russian Academy of Sciences, Prospect 100 Let Vladivostoku 159, 690022 Vladivostok, Russia

${ }^{2}$ Laboratory of Food Science and Technology, Department of Applied Biology and Chemistry, Tokyo University of Agriculture, 1-1-1 Sakuragaoka, Setagaya-ku, Tokyo 156-8502, Japan
\end{abstract}

The family Flavobacteriaceae, belonging to the phylum Bacteroidetes (the Cytophaga-Flavobacterium-Bacteroides group), was proposed by Reichenbach (1992) and subsequently described and emended by Bernardet et al. (1996, 2002). The taxonomy of the family Flavobacteriaceae, as well as the ecology and biotechnological applications of its members, have been summarized by Bernardet et al. (2002) and Bernardet \& Nakagawa (2003). The genus Salegentibacter (type species, Salegentibacter salegens) has been described by McCammon \& Bowman (2000) as the result of the reclassification of the marine halotolerant bacterium [Flavobacterium] salegens described by Dobson et al. (1993). Four novel Salegentibacter species have been described subsequently: Salegentibacter holothuriorum (Nedashkovskaya et al., 2004), S. mishustinae (Nedashkovskaya et al., 2005a), S. agarivorans (Nedashkovskaya et al., 2006) and S. flavus (Ivanova et al., 2006). The genus Salegentibacter is one of the marine members of the family Flavobacteriaceae, which also includes the genera Zobellia (Barbeyron et al., 2001), Muricauda (Bruns et al., 2001), Tenacibaculum (Suzuki

The GenBank/EMBL/DDBJ accession number for the 16S rRNA gene sequence of strain $\mathrm{KMM} 3046^{\top}$ is $\mathrm{AB} 261012$.

A maximum-likelihood phylogenetic tree, a scanning electron micrograph and a two-dimensional thin-layer chromatogram for strain KMM $3046^{\top}$ are available as supplementary material in IJSEM Online. et al., 2001), Aequorivita (Bowman \& Nichols, 2002), Croceibacter (Cho \& Giovannoni, 2003), Algoriphagus, Brumimicrobium, Cryomorpha and Crocinitomix (Bowman et al., 2003), Mesonia (Nedashkovskaya et al., 2003) and Leeuwenhoekiella (Nedashkovskaya et al., 2005b).

During a survey of the biodiversity of micro-organisms associated with marine invertebrates in the Fiji Sea, an aerobic, Gram-negative, yellow-pigmented bacterium, strain $\mathrm{KMM} 3046^{\mathrm{T}}$, was isolated from an unidentified deep-sea brittle-star specimen and was characterized using phenotypic and phylogenetic analyses. 16S rRNA gene sequence analysis demonstrated that the isolate forms a distinct phylogenetic lineage within the family Flavobacteriaceae, adjacent to members of the genus Salegentibacter (92.3-91.9\% sequence similarities). A number of phenotypic properties were found that serve to discriminate strain KMM $3046^{\mathrm{T}}$ from Salegentibacter species and from other phylogenetically related taxa. On the basis of these data, we concluded that the novel isolate KMM $3046^{\mathrm{T}}$ represents a novel genus and species.

A brittle star (ophiuroid) specimen (Ophiuroidea, Echinodermata) was collected from the Fiji Sea at a depth of $480 \mathrm{~m}$ in December 1991. The specimen was rinsed carefully with sterile seawater and cut aseptically. A small amount of tissue was crushed using a sterile mortar and pestle, and an aliquot of the diluted homogenate was spread 
on seawater-medium agar plates containing the following $\left(1^{-1}\right)$ : peptone, $5.0 \mathrm{~g}$; yeast extract, $2.5 \mathrm{~g}$; glucose, $1.0 \mathrm{~g}$; $\mathrm{K}_{2} \mathrm{HPO}_{4}, 0.2 \mathrm{~g}$; $\mathrm{MgSO}_{4}, 0.05 \mathrm{~g}$; and agar, $15.0 \mathrm{~g}$; made up in a seawater/distilled water mixture $(750$ and $250 \mathrm{ml}$, respectively). The plates were incubated at $28^{\circ} \mathrm{C}$ for 14 days. Each colony was picked up and restreaked on agar before being processed further. Strain KMM $3046^{\mathrm{T}}$ grew aerobically on seawater-medium agar, marine agar 2216 (MA; Difco) or marine broth 2216 (Difco) at $25-28^{\circ} \mathrm{C}$, and was stored at $-80^{\circ} \mathrm{C}$ in marine broth 2216 supplemented with $30 \%$ (v/v) glycerol. Flagellar motility was investigated by using the hanging drop method. Gliding motility was investigated using the same method (Bernardet et al., 2002) and as described by Bowman (2000). Cell morphology was examined using scanning electron microscopy of cells grown on MA at $25^{\circ} \mathrm{C}$ for 3 days. The cell suspension was diluted and the cells were fixed with $1 \%$ glutaraldehyde and then filtered $(0.2 \mu \mathrm{m}$ pore size; Nuclepore). Subsequently, the filters were processed by sequential ethanol dehydration and drying with $\mathrm{CO}_{2}$. The samples were then overlaid with gold and examined with a scanning electron microscope (S570; Hitachi). The presence of flexirubin pigments was investigated as described by Fautz \& Reichenbach (1980). The Gram, oxidase and catalase reactions and the hydrolysis of casein, alginate, cellulose (CM-cellulose and filter paper), chitin, gelatin and Tweens 20,40, 80 were tested according to the standard methods described by Smibert \& Krieg (1994). The hydrolysis of starch was investigated, after 2 days incubation on MA containing $0.2 \%(\mathrm{w} / \mathrm{v})$ soluble starch, by flooding the plates with a $1 \%(\mathrm{w} / \mathrm{v})$ iodine solution. The formation of $\mathrm{H}_{2} \mathrm{~S}$ from thiosulfate was tested using a lead acetate paper strip. Acid production from carbohydrates was examined using an oxidation/fermentation medium for marine bacteria (Leifson, 1963). Growth at different temperatures and $\mathrm{pH}$ and in the presence of various $\mathrm{NaCl}$ concentrations, the hydrolysis of various substrates and antibiotic resistance were studied as described previously (Romanenko et al., $2003,2004)$. In addition, biochemical tests were carried out using API 20NE test kits as described by the manufacturer (bioMérieux), except that the culture was suspended in a $2 \%(\mathrm{w} / \mathrm{v}) \mathrm{NaCl}$ solution. The API test results were read after incubation at $25^{\circ} \mathrm{C}$ for 24 and $48 \mathrm{~h}$. DNA was isolated by using the procedure of Marmur (1961). The DNA G+C content was determined by using the method of Marmur \& Doty (1962) as modified by Owen et al. (1969). For polar lipid and fatty acid analyses, strain $\mathrm{KMM} 3046^{\mathrm{T}}$ was cultivated on MA at $25^{\circ} \mathrm{C}$ for 3 days and the lipids were extracted using the chloroform/methanol method of Bligh \& Dyer (1959). The polar lipids were analysed using the methods of Rowe et al. (2000) and Vaskovsky \& Terekhova (1979). Two-dimensional TLC of the polar lipids was carried out using chloroform/methanol/benzene/28\% $\quad \mathrm{NH}_{4} \mathrm{OH}$ $(65: 30: 10: 6$, by vol.) for the first direction and chloroform/methanol/benzene/acetone/acetic acid/water $(70: 30: 10: 5: 4: 1$, by vol.) for the second direction. Nonspecific TLC detection of lipids was conducted with $10 \%$ $\mathrm{H}_{2} \mathrm{SO}_{4}$ in methanol at $180^{\circ} \mathrm{C}$. Amino-group-containing lipids were determined with ninhydrin, phospholipids were determined with molybdate reagent, glycolipids were determined with anthrone spray and choline lipids were determined with Dragendorff's reagent. Fatty acid methyl esters were obtained by alkaline methanolysis $(15 \% \mathrm{NaOH} /$ methanol) followed by acid methanolysis (2 M HCl/ methanol) as described by Nichols et al. (1993). The resultant fatty acid methyl esters were extracted by hexane and analysed using a GLC-MS Hewlett Packard gas chromatograph (model 6890) equipped with a Hewlett Packard 5 MS $5 \%$ phenyl methyl siloxane capillary column $(30 \mathrm{~m} \times 250 \mu \mathrm{m} \times 0.25 \mu \mathrm{m})$ and connected to a Hewlett Packard mass spectrometer (model 5973). Identification of the fatty acid methyl esters was achieved by using equivalent chain-length values and comparing the retention times of the samples with those of standards. Cellular quinones were determined by HPLC (LC-6A; Shimadzu) using a Cosmosil $5 \mathrm{C}_{18}$ column $(4.6 \times 150 \mathrm{~mm})$, with acetonitrile/2-propanol $(50: 50, \mathrm{v} / \mathrm{v})$ as the eluant $\left(0.5 \mathrm{ml} \mathrm{min}^{-1}\right)$ at a temperature of $40^{\circ} \mathrm{C}$ and with an SPD-2AM $(270 \mathrm{~nm}) \mathrm{UV}$ detector. The yellow pigments were studied following chloroform/methanol $(8: 1, \mathrm{v} / \mathrm{v})$ extraction. A non-polar pigment was isolated by preparative TLC and eluted with hexane; the visible spectrum of the hexane extract was examined with a spectrophotometer (model 7250; Cecil Instruments). The 16S rRNA gene sequence of strain KMM $3046^{\mathrm{T}}$ was determined as described by Shida et al. (1997) and compared with 16S rRNA gene sequences retrieved from the EMBL/GenBank/DDBJ databases, by using the FASTA program (Pearson \& Lipman, 1988). Distances were calculated according to the method of Jukes \& Cantor (1969). Phylogenetic trees were constructed using the neighbour-joining method of Saitou \& Nei (1987), with the CLUSTAL X program (version 1.8; Thompson et al., 1997), and using the maximum-likelihood method, with the BioEdit program (Hall, 1999). Bootstrap analysis was applied with the programs implemented in the PHYLIP package (Felsenstein, 1993), using 1000 resamplings of the dataset.

Phylogenetic analysis based on the almost-complete 16S rRNA gene sequence (1397 nt) of strain KMM $3046^{\mathrm{T}}$ revealed that $S$. holothuriorum $\mathrm{KMM} 3524^{\mathrm{T}}$ (Nedashkovskaya et al., 2004) and S. flavus KMM $6000^{\mathrm{T}}$ (Ivanova et al., 2006) are the closest phylogenetic neighbours, showing 92.3 and $92.1 \%$ sequence similarity, respectively, and that the type strain of the type species of the genus, S. salegens DSM $5424^{\mathrm{T}}$, and the distantly related species Mesonia algae $\mathrm{KMM} 3909^{\mathrm{T}}$ each show $<92 \%$ sequence similarity with respect to the isolate. The neighbour-joining tree (Fig. 1) showed that strain KMM $3046^{\mathrm{T}}$ forms a separate evolutionary lineage between the Salegentibacter and Aequorivita/Leeuwenhoekiella lineages within the family Flavobacteriaceae. The maximumlikelihood tree showed a rather different topology, but the relationships between KMM $3046^{\mathrm{T}}$ and Mesonia algae and Salegentibacter species were still apparent (see Supplementary Fig. S1 available in IJSEM Online). The 


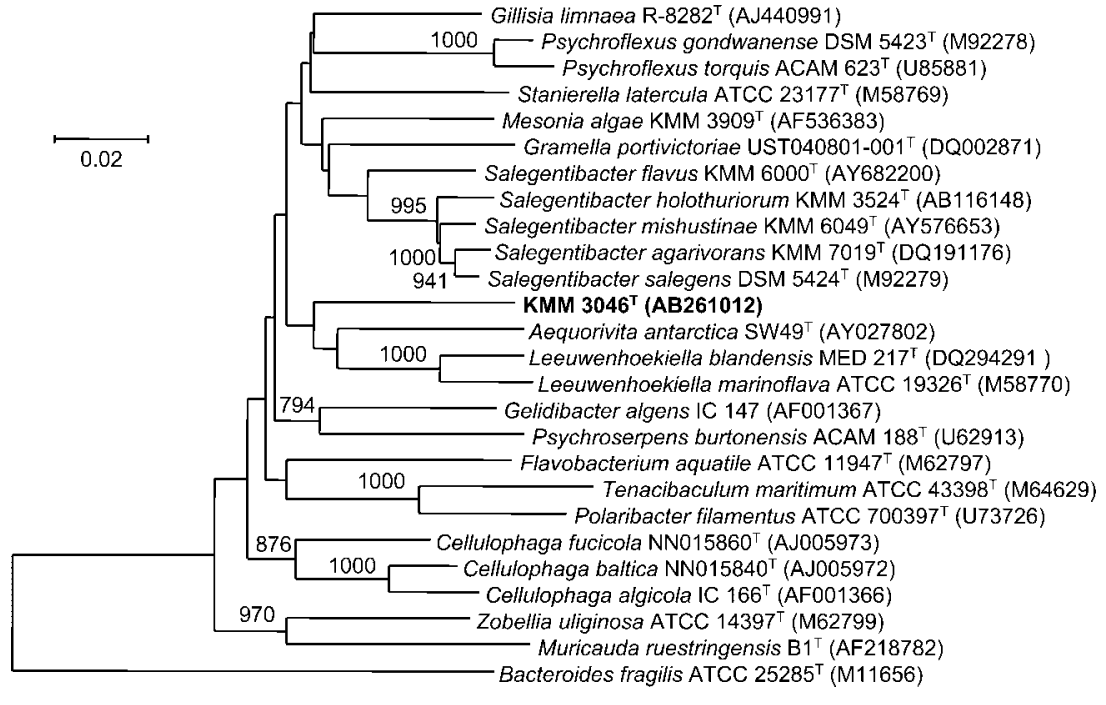

Fig. 1. Neighbour-joining phylogenetic tree, based on 16S rRNA gene sequences, showing the relationships of strain KMM $3046^{\top}$ and related taxa. Numbers at nodes indicate bootstrap values greater than 700 (from 1000 resamplings of the dataset). Bar, 0.02 substitutions per nucleotide position. morphological, physiological, biochemical and chemotaxonomic characteristics of strain KMM $3046^{\mathrm{T}}$ are given in Table 1 and in the genus and species descriptions (and in Supplementary Table S1 and Supplementary Fig. S2, available in IJSEM Online). Table 1 lists the phenotypic properties that serve to differentiate between strain KMM $3046^{\mathrm{T}}$ and members of the genera Salegentibacter, Mesonia, Aequorivita and Leeuwenhoekiella. Because of the variety in the phenotypic characteristics among members of the genus Salegentibacter, all five species were included in Table 1 . The major respiratory quinone of strain $\mathrm{KMM} 3046^{\mathrm{T}}$ was MK-6 and its DNA G $+\mathrm{C}$ content was $37.3 \mathrm{~mol} \%$. These features are in accordance with those of related organisms, except with regard to the $\mathrm{G}+\mathrm{C}$ contents of $S$. flavus, Mesonia algae and members of the genus Leeuwenhoekiella, which differ noticeably from that of strain KMM $3046^{\mathrm{T}}$.

The major cellular fatty acids of strain KMM $3046^{\mathrm{T}}$ are listed in the species description, and its detailed fatty acid composition is shown in Supplementary Table S1. Strain KMM $3046^{\mathrm{T}}$ is characterized by the presence of significant amounts of 3-OH i16:0 and 3-OH i17:0 (57.6\% of the total). The polar lipid composition of strain KMM $3046^{\mathrm{T}}$ included phosphatidylethanolamine, lysophosphatidylethanolamine, aminophospholipid, an unknown lipid and sphingolipid, the latter component being predominant (see Supplementary Fig. S3 available in IJSEM Online). One non-polar pigment was found, characterized by absorption peaks at 422 and $445 \mathrm{~nm}$, with a shoulder at $475 \mathrm{~nm}$. Consequently, strain KMM $3046^{\mathrm{T}}$ can be distinguished from members of the genera Salegentibacter, Mesonia, Aequorivita and Leeuwenhoekiella as well as from other members of the family Flavobacteriaceae on the basis of a combination of biochemical characteristics (Table 1), chemotaxonomic traits (Supplementary Table S1) and the phylogenetic distance (Fig. 1).

On the basis of these results, the novel isolate, strain KMM $3046^{\mathrm{T}}$, represents a novel genus and species, for which the name Marixanthomonas ophiurae gen. nov., sp. nov. is proposed.

\section{Description of Marixanthomonas gen. nov.}

Marixanthomonas (Ma'ri.xan'tho.mo'nas. L. n. mare the sea; Gr. adj. xanthos yellow; Gr. n. monas a unit, monad; N.L. fem. n. Marixanthomonas a marine yellow monad).

Cells are Gram-negative, non-motile, non-spore-forming rods. Strictly aerobic. Oxidase- and catalase-positive. Yellow-pigmented. Flexirubin pigments are not produced. Chemoorganotrophic, with an absolute requirement for sodium ions. Halophilic. The predominant menaquinone is MK-6. Polar lipids consist of sphingolipid, phosphatidylethanolamine, lysophosphatidylethanolamine, aminophospholipid and an unknown lipid. The major cellular fatty acids are $3-\mathrm{OH}$ i16:0, 3-OH i17:0, 3-OH a17:0, $16: 0$ and 18:0. Isolated from the marine environment. The DNA $\mathrm{G}+\mathrm{C}$ content of the type species is $37.3 \mathrm{~mol} \%$. Analysis of the 16S rRNA gene sequence shows that the genus belongs to the family Flavobacteriaceae. The type species is Marixanthomonas ophiurae.

\section{Description of Marixanthomonas ophiurae sp. nov.}

Marixanthomonas ophiurae (o.phi.u'rae. N.L. gen. n. ophiurae of Ophiura, a class of invertebrates belonging to the Ophiuroidea, the source of isolation of the type strain).

Possesses the following traits in addition to those reported for the genus. Cells are $0.4-0.5 \times 2.2-2.8 \mu \mathrm{m}$. On MA, colonies are round, $4-5 \mathrm{~mm}$ in diameter, smooth, shiny, opaque, slimy, light yellow (having a non-diffusible carotenoid pigment) and have regular edges. Grows in the presence of 1.0-12\% (w/v) NaCl (optimum, 3-5\%). Weak growth occurs with 1 and $12 \% \mathrm{NaCl}$. Psychrotolerant. Grows at $5-32^{\circ} \mathrm{C}$ (optimum, $25-28^{\circ} \mathrm{C}$ ) and grows slowly at $5{ }^{\circ} \mathrm{C}$; no growth occurs above $33^{\circ} \mathrm{C}$. The optimal $\mathrm{pH}$ for 
Table 1. Differential characteristics of strain $\mathrm{KMM} 3046^{\top}$ and related taxa

Strains/species: 1, KMM 3046 ${ }^{\mathrm{T}}$; 2, S. salegens DSM 5424 ${ }^{\mathrm{T}}$; 3, S. mishustinae KMM 6049 ${ }^{\mathrm{T}}$; 4, S. holothuriorum KMM 3524 ; 5, S. flavus

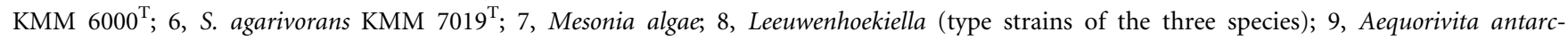
tica. Data are from Dobson et al. (1993), McCammon \& Bowman (2000), Nedashkovskaya et al. (2003, 2004, 2005a, b), Ivanova et al. (2006), Pinhassi et al. (2006), Bowman \& Nichols (2002) and this study. All taxa are negative for anaerobic growth, the production of flexirubin pigments, the hydrolysis of chitin and cellulose (CM-cellulose and filter paper) and the production of indole. All taxa are positive for gelatin hydrolysis, the production of oxidase and catalase and growth in $6 \% \mathrm{NaCl}$. Abbreviations: + , positive; - , negative; w, weak reaction; V, variable reaction between strains or species; ND, no data available.

\begin{tabular}{|c|c|c|c|c|c|c|c|c|c|}
\hline Characteristic & 1 & 2 & 3 & 4 & 5 & 6 & 7 & 8 & 9 \\
\hline Gliding motility & - & - & - & - & - & + & - & + & - \\
\hline Nitrate reduction & - & + & - & - & - & + & - & - & - \\
\hline $\mathrm{Na}^{+}$requirement & + & - & + & + & + & + & + & - & + \\
\hline \multicolumn{10}{|l|}{ Growth at: } \\
\hline $34^{\circ} \mathrm{C}$ & - & + & + & + & + & + & + & + & - \\
\hline $41^{\circ} \mathrm{C}$ & - & - & - & - & - & + & - & $\mathrm{V}$ & - \\
\hline \multicolumn{10}{|l|}{ Tolerance of $\mathrm{NaCl}$ at: } \\
\hline $8 \%$ & + & + & + & + & + & + & + & + & - \\
\hline $12 \%$ & $\mathrm{~W}$ & + & + & - & - & + & + & + & - \\
\hline $15 \%$ & - & + & + & - & - & + & + & + & - \\
\hline $18 \%$ & - & + & + & - & - & + & - & - & - \\
\hline \multicolumn{10}{|l|}{ Hydrolysis of: } \\
\hline Casein & + & - & + & - & - & - & + & + & - \\
\hline Starch & - & + & + & + & + & + & - & + & + \\
\hline Alginate & - & + & + & + & $\mathrm{ND}$ & + & - & $\mathrm{ND}$ & - \\
\hline Agar & - & - & - & - & - & + & - & - & - \\
\hline Urea & - & - & - & - & + & - & - & - & $\mathrm{V}$ \\
\hline Acid from sugars & - & + & + & + & - & + & - & + & - \\
\hline $\mathrm{H}_{2} \mathrm{~S}$ production & - & + & + & + & - & + & + & - & - \\
\hline DNA G $+C$ content $(\mathrm{mol} \%)$ & 37.3 & 37.8 & 37.5 & 37.5 & $40.4 \pm 0.5$ & 39.2 & $32.7-34.0$ & $35-42.5$ & $38-39$ \\
\hline
\end{tabular}

growth is 6.5-8.5. Negative results in the Simmons' citrate test and the Voges-Proskauer test; negative for $\mathrm{H}_{2} \mathrm{~S}$, arginine dihydrolase, ornithine and lysine decarboxylases and phenylalanine deaminase; negative for nitrate reduction and for the utilization of D-glucose, L-arabinose, lactose, Dmannose, sucrose, inositol, sorbitol, mannitol, citrate and malonate (using conventional methods). Negative in API 20NE kits for the production of arginine dihydrolase, urease and indole, in the ONPG test, for the hydrolysis of aesculin and for the utilization of glucose, L-arabinose, D-mannose, $\mathrm{N}$-acetylglucosamine, maltose, D-gluconate, caprate, adipate, L-malate, citrate and phenylacetate. Starch, aesculin, alginate, agar, cellulose (CM-cellulose or filter paper) and chitin are not hydrolysed. Gelatin is hydrolysed in 3-4 days when tested using a conventional method, and in $24 \mathrm{~h}$ in the API 20NE test. Tweens 80,40 and 20 are hydrolysed. Acid is not produced from D-glucose, D-xylose, rhamnose, fructose, galactose, maltose, sucrose, lactose, arabinose, $\mathrm{N}$-acetylglucosamine, mannitol, inositol or glycerol. Other physiological characteristics are listed in Table 1. Susceptible to (content per disc) lincomycin $(15 \mu \mathrm{g})$, erythromycin $(15 \mu \mathrm{g})$, carbenicillin $(100 \mu \mathrm{g})$, oleandomycin $(15 \mu \mathrm{g})$, streptomycin $(30 \mu \mathrm{g})$ (weakly) and chloramphenicol $(30 \mu \mathrm{g})$, and resistant to ampicillin $(10 \mu \mathrm{g})$, benzylpenicillin
(10 U), gentamicin $(10 \mu \mathrm{g})$, kanamycin $(30 \mu \mathrm{g})$, neomycin $(30 \mu \mathrm{g})$, polymyxin $\mathrm{B}(300 \mathrm{U})$, tetracycline $(30 \mu \mathrm{g})$ and doxycycline $(10 \mu \mathrm{g})$. The major fatty acids are 3-OH i16:0 (41.2\%), 3-OH i17:0 (16.4\%), 3-OH a17:0 (5.1\%), 16:0 $(6.9 \%)$ and $18: 0(5.2 \%)$. Other fatty acids present are as follows: i15:0 (2.9\%), 15:0 (2.4\%), $15: 1$ (1.3\%), i16:0 (1.8\%), $2-\mathrm{OH} 15: 0(3.3 \%), 3-\mathrm{OH} 16: 0$ (4.4\%), $3-\mathrm{OH}$ $17: 0(2.5 \%)$ and $18: 1 \omega 9 c(3.9 \%)$. The polar lipid composition is as given in the genus description, with sphingolipid as the predominant compound. The non-polar pigment is characterized by absorption peaks at 422 and $445 \mathrm{~nm}$, with a shoulder at $475 \mathrm{~nm}$. The DNA G+C content is $37.3 \mathrm{~mol} \%$.

The type strain, KMM $3046^{\mathrm{T}}$ (=NRIC $0684^{\mathrm{T}}=\mathrm{JCM}$ $14121^{\mathrm{T}}$ ), was isolated from an ophiuroid specimen collected from the Fiji Sea at a depth of $480 \mathrm{~m}$.

\section{Acknowledgements}

This study was supported by a grant from the Russian Foundation for Basic Research and the Far-Eastern Branch of the Russian Academy of Sciences (06-04-96007, grant 06-III-A-06183), and by grants from Rosnauka KMM and Scientific Schools. 


\section{References}

Barbeyron, T., L'Haridon, S., Corre, E., Kloareg, B. \& Potin, P. (2001). Zobellia galactanovorans gen. nov., sp. nov., a marine species of Flavobacteriaceae isolated from a red alga, and classification of [Cytophaga] uliginosa (ZoBell and Upham 1944) Reichenbach 1989 as Zobellia uliginosa gen. nov., comb. nov. Int J Syst Evol Microbiol 51, 985-997.

Bernardet, J.-F. \& Nakagawa, Y. (2003). An introduction to the family Flavobacteriaceae. In The Prokaryotes, An Evolving Electronic Resource for the Microbiological Community, release 3.15. Edited by M. Dworkin, S. Falkow, E. Rosenberg, K.-H. Schleifer \& E. Stackebrandt. New York: Springer. http://link.springer-ny.com/ link/service/books/10125/

Bernardet, J.-F., Segers, P., Vancanneyt, M., Berthe, F., Kersters, K. \& Vandamme, P. (1996). Cutting a Gordian knot: emended classification and description of the genus Flavobacterium, emended description of the family Flavobacteriaceae, and proposal of Flavobacterium hydatis nom. nov. (basonym, Cytophaga aquatilis Strohl and Tait 1978). Int J Syst Bacteriol 46, 128-148.

Bernardet, J.-F., Nakagawa, Y. \& Holmes, B. (2002). Proposed minimal standards for describing new taxa of the family Flavobacteriaceae and emended description of the family. Int J Syst Evol Microbiol 52, 1049-1070.

Bligh, E. G. \& Dyer, W. J. (1959). A rapid method of total lipid extraction and purification. Can J Biochem Physiol 37, 911-917.

Bowman, J. P. (2000). Description of Cellulophaga algicola sp. nov., isolated from the surface of Antarctic algae, and reclassification of Cytophaga uliginosa (ZoBell and Upham 1944) Reichenbach 1989 as Cellulophaga uliginosa comb. nov. Int J Syst Evol Microbiol 50, 1861-1868.

Bowman, J. P. \& Nichols, D. S. (2002). Aequorivita gen. nov., a member of the family Flavobacteriaceae isolated from terrestrial and marine Antarctic habitats. Int J Syst Evol Microbiol 52, 1533-1541.

Bowman, J. P., Nichols, C. M. \& Gibson, J. A. E. (2003). Algoriphagus ratkowskyi gen. nov., sp. nov., Brumimicrobium glaciale gen. nov., sp. nov., Cryomorpha ignava gen. nov., sp. nov. and Crocinitomix catalasitica gen. nov., sp. nov., novel flavobacteria isolated from various polar habitats. Int J Syst Evol Microbiol 53, 1343-1355.

Bruns, A., Rohde, M. \& Berthe-Corti, L. (2001). Muricauda ruestringensis gen. nov., sp. nov., a facultatively anaerobic, appendaged bacterium from German North Sea intertidal sediment. Int J Syst Evol Microbiol 51, 1997-2006.

Cho, J. C. \& Giovannoni, S. J. (2003). Croceibacter atlanticus gen. nov., sp. nov., a novel marine bacterium in the family Flavobacteriaceae. Syst Appl Microbiol 26, 76-83.

Dobson, S. J., Colwell, R. R., McMeekin, T. A. \& Franzmann, P. D. (1993). Direct sequencing of the polymerase chain reaction-amplified $16 \mathrm{~S}$ rRNA gene of Flavobacterium gondwanense sp. nov. and Flavobacterium salegens sp. nov., two new species from a hypersaline Antarctic lake. Int J Syst Bacteriol 43, 77-83.

Fautz, E. \& Reichenbach, H. (1980). A simple test for flexirubin-type pigments. FEMS Microbiol Lett 8, 87-91.

Felsenstein, J. (1993). PHYLIP (phylogeny inference package), version 3.5.1. Department of Genome Sciences, University of Washington, Seattle, USA.

Hall, T. A. (1999). BioEdit: a user-friendly biological sequence alignment editor and analysis program for Windows 95/98/NT. Nucleic Acids Symp Ser 41, 95-98.

Ivanova, E. P., Bowman, J. P., Christen, R., Zhukova, N. V., Lysenko, A. M., Gorshkova, N. M., Mitik-Dineva, N., Sergeev, A. F. \& Mikhailov, V. V. (2006). Salegentibacter flavus sp. nov. Int J Syst Evol Microbiol 56, 583-586.
Jukes, T. H. \& Cantor, C. R. (1969). Evolution of protein molecules. In Mammalian Protein Metabolism, pp. 21-132. Edited by H. N. Munro. New York: Academic Press.

Leifson, E. (1963). Determination of carbohydrate metabolism of marine bacteria. J Bacteriol 85, 1183-1184.

Marmur, J. (1961). A procedure for the isolation of deoxyribonucleic acid from microorganisms. J Mol Biol 3, 208-218.

Marmur, J. \& Doty, P. (1962). Determination of the base composition of deoxyribonucleic acid from its thermal denaturation temperature. J Mol Biol 5, 109-118.

McCammon, S. A. \& Bowman, J. P. (2000). Taxonomy of Antarctic Flavobacterium species: description of Flavobacterium gillisiae sp. nov., Flavobacterium tegetincola sp. nov. and Flavobacterium xanthum sp. nov., nom. rev. and reclassification of [Flavobacterium] salegens as Salegentibacter salegens gen. nov., comb. nov. Int J Syst Evol Microbiol 50, 1055-1063.

Nedashkovskaya, O. I., Kim, S. B., Han, S. K., Lysenko, A. M., Rohde, M., Zhukova, N. V., Falsen, E., Frolova, G. M., Mikhailov, V. V. \& other authors (2003). Mesonia algae gen. nov., sp. nov., a novel marine bacterium of the family Flavobacteriaceae isolated from the green alga Acrosiphonia sonderi (Kütz) Kornm. Int J Syst Evol Microbiol 53, 1967-1971.

Nedashkovskaya, O. I., Suzuki, M., Vancanneyt, M., Cleenwerck, I., Zhukova, N. V., Vysotskii, M. V., Mikhailov, V. V. \& Swings, J. (2004). Salegentibacter holothuriorum sp. nov., isolated from the edible holothurian Apostichopus japonicus. Int J Syst Evol Microbiol 54, 1107-1110.

Nedashkovskaya, O. I., Kim, S. B., Lysenko, A. M., Mikhailov, V. V., Bae, K. S. \& Kim, I. S. (2005a). Salegentibacter mishustinae sp. nov, isolated from the sea urchin Strongylocentrotus intermedius. Int J Syst Evol Microbiol 55, 235-237.

Nedashkovskaya, O. I., Vancanneyt, M., Dawyndt, P., Engelbeen, K., Vandemeulebroecke, K., Cleenwerck, I., Hoste, B., Mergaert, J., Tan, T. L. \& other authors (2005b). Reclassification of [Cytophaga] marinoflava Reichenbach 1989 as Leeuwenhoekiella marinoflava gen. nov., comb. nov. and description of Leeuwenhoekiella aequorea sp. nov. Int J Syst Evol Microbiol 55, 1033-1038.

Nedashkovskaya, O. I., Kim, S. B., Vancanneyt, M., Shin, D. S., Lysenko, A. M., Shevchenko, L. S., Krasokhin, V. B., Mikhailov, V. V., Swings, J. \& Bae, K. S. (2006). Salegentibacter agarivorans sp. nov., a novel marine bacterium of the family Flavobacteriaceae isolated from the sponge Artemisina sp. Int J Syst Evol Microbiol 56, 883-887.

Nichols, D. S., Nichols, P. D. \& McMeekin, T. A. (1993). Polyunsaturated fatty acids in Antarctic bacteria. Antarct Sci 5, 149-160.

Owen, J., Hill, L. R. \& Lapage, S. P. (1969). Determination of DNA base composition from melting profiles in dilute buffers. Biopolymers 7, 503-516.

Pearson, W. \& Lipman, D. J. (1988). Improved tools for biological sequence comparison. Proc Natl Acad Sci U S A 85, 2444-2448.

Pinhassi, J., Bowman, J. P., Nedashkovskaya, O. I., Lekunberri, I., Gomez-Consarnau, L. \& Pedrós-Alió, C. (2006). Leeuwenhoekiella blandensis sp. nov., a genome-sequenced marine member of the family Flavobacteriaceae. Int J Syst Evol Microbiol 56, 1489-1493.

Reichenbach, H. (1992). The order Cytophagales. In The Prokaryotes. A Handbook on the Biology of Bacteria: Ecophysiology, Isolation, Identification, Applications, 2nd edn, pp. 3631-3675. Edited by A. Balows, H. G. Trüper, M. Dworkin, W. Harder \& K. H. Schleifer. New York: Springer.

Romanenko, L. A., Uchino, M., Falsen, E., Zhukova, N. V., Mikhailov, V. V. \& Uchimura, T. (2003). Rheinheimera pacifica sp. nov., a novel halotolerant bacterium isolated from the deep sea of the Pacific. Int J Syst Evol Microbiol 53, 1973-1977. 
Romanenko, L. A., Schumann, P., Rohde, M., Mikhailov, V. V. \& Stackebrandt, E. (2004). Reinekea marinisedimentorum gen. nov., sp. nov., a novel gammaproteobacterium from marine coastal sediments. Int J Syst Evol Microbiol 54, 669-673.

Rowe, N. J., Tunstall, J., Galbraith, L. \& Wilkinson, S. G. (2000). Lipid composition of [Pseudomonas] echinoides: transfer to the genus Sphingomonas. Microbiology 146, 3007-3012.

Saitou, N. \& Nei, M. (1987). The neighbor-joining method: a new method for reconstructing phylogenetic trees. Mol Biol Evol 4, 406-425.

Shida, O., Takagi, H., Kadowaki, K., Nakamura, L. K. \& Komagata, K. (1997). Transfer of Bacillus alginolyticus, Bacillus chondroitinus, Bacillus curdlanolyticus, Bacillus glucanolyticus, Bacillus kobensis, and Bacillus thiaminolyticus to the genus Paenibacillus and emended description of the genus Paenibacillus. Int J Syst Bacteriol 47, 289-298.

Smibert, R. M. \& Krieg, N. R. (1994). Phenotypic characterization. In Methods for General and Molecular Bacteriology, pp. 607-654. Edited by P. Gerhardt, R. G. E. Murray, W. A. Wood \& N. R. Krieg. Washington, DC: American Society for Microbiology.

Suzuki, M., Nakagawa, Y., Harayama, S. \& Yamamoto, S. (2001). Phylogenetic analysis and taxonomic study of marine Cytophaga-like bacteria: proposal for Tenacibaculum gen. nov. with Tenacibaculum maritimum comb. nov. and Tenacibaculum ovolyticum comb. nov., and description of Tenacibaculum mesophilum sp. nov. and Tenacibaculum amylolyticum sp. nov. Int J Syst Evol Microbiol 51, 1639-1652.

Thompson, J. D., Gibson, T. J., Plewniak, F., Jeanmougin, F. \& Higgins, D. G. (1997). The CLUSTAL_X windows interface: flexible strategies for multiple sequence alignment aided by quality analysis tools. Nucleic Acids Res 25, 4876-4882.

Vaskovsky, V. E. \& Terekhova, T. A. (1979). HPTLC of phospholipid mixtures containing phosphatidylglycerol. J High Resolut Chromatogr 2, 671-672. 